\title{
Patient-matched positioning guides in total knee arthroplasty
}

Citation for published version (APA):

Boonen, B. (2017). Patient-matched positioning guides in total knee arthroplasty. [Doctoral Thesis, Maastricht University]. Datawyse / Universitaire Pers Maastricht. https://doi.org/10.26481/dis.20170217bb

Document status and date:

Published: 01/01/2017

DOI:

10.26481/dis.20170217bb

Document Version:

Publisher's PDF, also known as Version of record

\section{Please check the document version of this publication:}

- A submitted manuscript is the version of the article upon submission and before peer-review. There can be important differences between the submitted version and the official published version of record.

People interested in the research are advised to contact the author for the final version of the publication, or visit the DOI to the publisher's website.

- The final author version and the galley proof are versions of the publication after peer review.

- The final published version features the final layout of the paper including the volume, issue and page numbers.

Link to publication

\footnotetext{
General rights rights.

- You may freely distribute the URL identifying the publication in the public portal. please follow below link for the End User Agreement:

www.umlib.nl/taverne-license

Take down policy

If you believe that this document breaches copyright please contact us at:

repository@maastrichtuniversity.nl

providing details and we will investigate your claim.
}

Copyright and moral rights for the publications made accessible in the public portal are retained by the authors and/or other copyright owners and it is a condition of accessing publications that users recognise and abide by the legal requirements associated with these

- Users may download and print one copy of any publication from the public portal for the purpose of private study or research.

- You may not further distribute the material or use it for any profit-making activity or commercial gain

If the publication is distributed under the terms of Article $25 \mathrm{fa}$ of the Dutch Copyright Act, indicated by the "Taverne" license above, 


\section{Chapter 10}

\section{Summary}

Nederlandse samenvatting 



\section{SUMMARY}

In this thesis the potential of patient-matched positioning guides (PMPG) as an alignment tool for performing a total knee arthroplasty (TKA) was explored. PMPG uses patient-specific guides to make bony resections of femur and tibia. Imaging techniques and a specific software program are used to create virtual models of the patient's femur and tibia. CT-scan or MRI-scan are the basic imaging modalities. The virtual models are then used to identify anatomical landmarks of the knee which are used to calculate ideal implant size and positioning. These calculations subsequently result in a virtual plan of the operation to be performed in theatre. The final step is to create alignment guides that have only one fitting position on the patient's individual femoral and tibial anatomy. They dictate bony resections in the preparation for prosthesis placement.

In chapter 1 we discussed that the number of patients receiving a TKA has risen substantially over de past years and is expected to continue to rise in the years to come. We briefly discussed conventional instruments and computer assisted surgery as alignment methods for performing a TKA and outlined most of the disadvantages associated with these techniques. PMPG attempts to address these disadvantages of existing alignment techniques and claims to offer part of the solutions for the challenges that come with the growing demand in TKA surgery.

Most surgeons nowadays use conventional intramedullary or extramedullary alignment guides (conventional instruments: $\mathrm{Cl}$ ) for aligning a TKA. In this thesis we therefore compared results of PMPG to results obtained with $\mathrm{Cl}$.

In chapter 2, we presented the results of the first 40 consecutive patients operated on by means of PMPG for TKA. We conducted a case control study and compared blood loss, operation time, and alignment of 40 TKA's using PMPG with a matched control group, operated on by $\mathrm{Cl}$.

We concluded from this chapter that PMPG TKA shows improved accuracy of alignment and a small decrease in blood loss $(60 \mathrm{~mL})$ and operating time (10 $\mathrm{min}$ ) compared to $\mathrm{Cl}$ but the fraction of outliers (more than 3 degrees deviation from neutral mechanical axis of the leg) was relatively high (30\% versus $50 \%$ with $\mathrm{Cl}$ ).

The preliminary experience with PMPG was generally positive in comparison with $\mathrm{Cl}$ and therefore we aimed at investigating the technique in more detail by setting up a randomized controlled trial comparing these 2 alignment methods. The results of this trial were outlined in chapter 4 and chapter 5 . However, as the fraction of outliers in mechanical axis was higher than expected, we set up a separate study to assess the potential weak spot of PMPG as an alignment method. As the basic aim of PMPG is to adequately recreate the pre-operative digital plan, we investigated the potential of the technique to do so in chapter 3. 
More specifically, the goal of chapter 3 was to explore whether there was a significant difference between the alignment of the individual femoral and tibial components of a TKA (in the frontal, sagittal and horizontal planes) as calculated pre-operatively (digital plan) and the actually achieved alignment in vivo obtained with the use of PMPG for TKA.

Twenty-six patients were included in this trial. Software permitted matching of the pre-operative MRI-scan (and therefore calculated prosthesis position) to a preoperative CT-scan and then to a post-operative full-leg CT-scan to determine deviations from pre-op planning in all 3 anatomical planes.

We concluded from this chapter that PMPG were able to adequately reproduce the pre-op plan in all planes, except for the tibial rotation in the transverse plane. We discussed and highlighted the importance for adequate surgeon training before starting using PMPG.

As already stated, the results outlined in chapter 2 prompted us to conduct a prospective, double-blind, randomized controlled trial. Chapter 4 describes this trial and addresses the following research questions: firstly, is there a significant difference in outliers in alignment in the frontal and sagittal plane between PMPG TKA and CI TKA. Secondly, is there a significant difference in operation time, blood loss and length of hospital stay between the two techniques. One hundred and eighty patients were randomized for PMPG TKA or CI TKA in two centers.

We concluded from this chapter that the results in terms of obtaining a neutral mechanical axis and a correct position of the prosthesis components did not differ between PMPG and $\mathrm{Cl}$. A small reduction in operation time $(5$ minutes, $\mathrm{p}<0.001)$ and blood loss $(100 \mathrm{~mL}, \mathrm{p}<0.001)$ can be realised with the PMPG system, but length of hospital stay was identical (mean of 3.6 days, n.s.) compared to $\mathrm{Cl}$.

In chapter 5 we presented the clinical outcome and complication rate of PMPG as medium-term results of the randomized controlled trial presented already in chapter 4.

We concluded that there were no significant or clinically relevant differences between $\mathrm{Cl}$ and PMPG TKA for all questionnaires and that there was no difference in TKA related complication rate.

From chapter 2, 3, 4 and 5 it was clear that PMPG were safe to use and at least not inferior to $\mathrm{Cl}$ in terms of obtaining a correct alignment or good clinical outcome. However based on the research presented in these chapters, no clear benefit of using PMPG over $\mathrm{Cl}$ could be demonstrated either. Theoretically, PMPG should be able to adequately predict implant size based on the preoperative images. Predicting this implant size could potentially reduce costs of TKA surgery and we investigated the sizing capabilities of PMPG in a separate study, presented next. 
In this study in chapter 6 , the initial series of 200 consecutive cases operated on by a single surgeon and with a minimum follow-up of 2 years was analyzed. Operation time, accuracy of component size prediction and percentages of outliers (>3 degrees) in mechanical axis were assessed in this cohort.

No cases in this series needed to be converted to traditional instrumentation. Average operation time was 52 minutes. No learning curve on surgical time was seen. Implanted component size prediction with an error of one size, was correct in $98.5 \%$ of femoral components and $97.0 \%$ of tibial components. Reviewing and approving the preoperative plan, reduced the number of changes that were necessary during surgery from $21.5 \%$ to $14 \%$ for the femoral component and from $41 \%$ to $29.5 \%$ for the tibial component. Average mechanical axis was $179.5^{\circ}$ with a percentage of outliers $>3^{\circ}$ from digital planning of $20.7 \%$.

We demonstrated in this chapter the importance of a critical review of the digital preoperative plan in order to be able to rely on the component sizing capabilities of PMPG. The question whether PMPG can reduce costs in TKA surgery is one that is difficult to answer and future research will be necessary to address this issue in more detail.

While conducting the research for this thesis, concerns had risen about the adequacy of measurements performed on standing long-leg radiographs (LLR). We used these radiographs throughout our research presented in the former chapters to assess alignment outcomes. We therefore aimed at assessing the reliability and validity of measurements on LLR using 3D CT-scan as a gold standard in the next chapter of this thesis.

In chapter 7, six different surgeons measured the mechanical axis and position of the femoral and tibial components individually on 24 LLR. Intraclass correlation coefficients were calculated to obtain reliability and bland-altman plots were constructed to assess agreement between measurements on LLR and measurements on 3D CT-scan.

We concluded from this chapter that measurements on LLR show moderate to good reliability and, when compared to 3D CT-scan, show good validity.

Finally, in chapter 8 we placed our findings in a broader context and answered the questions postulated in the introduction of this thesis (chapter 1 ).

In the second part of this chapter we discussed challenges when introducing PMPG on a larger scale in TKA surgery. Perhaps the most important question to be asked was how to deal with medicolegal issues of PMPG. Medico-legal experts have pointed out that companies are responsible if PMPG are created and delivered without validation of the planning by the surgeon. There is no doubt that the orthopaedic surgeon in the end is responsible for the correct placement of the TKA components.

Second major challenge when using PMPG is the peri-operative logistics issue. The pathway of performing an MRI or CT-scan, uploading the images to the engineer's server for construction of the digital plan, checking and approval of the digital plan by the 
operating surgeon, in time delivery of the guides and digital plan and sterilisation of the guides for peroperative use poses specific demands on the organization.

The third challenge is in the training of orthopaedic residents. Residents will have to learn to master both $\mathrm{CI}$ TKA and PMPG TKA and not just PMPG TKA. When the steps and the theoretical knowledge of performing a CI TKA are sufficiently mastered, PMPG can be safely learned.

In the Netherlands, every total knee that has been implanted is registered in a central database (LROI: landelijke registratie orthopedische implantaten). No information is gathered on the type of alignment method used when performing a TKA. With the introduction of more alignment techniques, it might be of interest, however, to collect this information as well. This will make it easier in the long term to draw conclusions on safety and number of needed revision procedures with each alignment technique.

We finally concluded by stating that PMPG definitively deserve a place as an alignment tool in TKA surgery. However, at this stage PMPG are more an evolution in TKA surgery than a revolution. 


\section{NEDERLANDSE SAMENVATTING}

In deze thesis werd het potentieel van patiënt-specifieke mallen (PSM) als een methode voor het uitlijnen van een totale knie prothese (TKP) geëxploreerd. Computer tomografie scans (CT-scans) of magneetscans (MRI-scans) en een specifiek software programma worden gebruikt om virtuele modellen van femur en tibia te construeren. Deze virtuele modellen worden vervolgens gebruikt om anatomische herkenningspunten te identificeren op de knie (door planningsingenieur) die vervolgens gebruikt worden om de ideale maat en positie van de prothesecomponenten te berekenen. Deze berekeningen worden vastgelegd in een virtueel plan van de operatie. De laatste stap is het creëren van uitlijningsmallen die slechts op één manier op femur en tibia van de patiënt in kwestie passen. Deze mallen bepalen vervolgens tijdens de operatie hoe de zaagsneden in het bot verlopen en bepalen daarmee de uiteindelijke positie van de knieprothese. Bij de meeste systemen van PSM wordt gestreefd naar het construeren van een neutrale/rechte beenas.

In hoofdstuk 1 hebben we beargumenteerd dat het aantal patiënten dat een TKP ondergaat substantieel toegenomen is in de afgelopen jaren en dat de verwachting is dat deze trend zich voortzet in de komende jaren. We bediscussieerden kort het conventioneel instrumentarium $(\mathrm{Cl})$ en computernavigatie als methoden voor het plaatsen van een TKP en beschreven de meeste nadelen die geassocieerd zijn met beide technieken. PSM tracht een antwoord te bieden op deze nadelen en claimt tevens een deel van de oplossing te zijn voor de uitdagingen die de groeiende vraag naar TKP's met zich meebrengt.

De meeste orthopedisch chirurgen gebruiken heden ten dage conventioneel intramedullaire of extramedullaire uitrichtapparaat $(\mathrm{CI})$ om een TKP te plaatsen. Om die reden vergelijken we in deze thesis de resultaten van PSM met die van $\mathrm{Cl}$.

In hoofdstuk 2 presenteren we de resultaten van de eerste 40 opeenvolgende patiënten die middels PSM een TKP geplaatst kregen. We voerden een case control studie uit en vergeleken bloedverlies, operatietijd en uitlijning van 40 TKP's die geplaatst werden met PSM met een gematchte controlegroep die middels $\mathrm{Cl}$ geopereerd werd.

We concludeerden uit dit hoofdstuk dat PSM een verbeterde accuratesse laat zien voor het uitlijnen van een prothese in termen van het verkrijgen van een neutrale beenas en bovendien zorgde voor een kleine reductie in operatietijd (10 min) en bloedverlies $(60 \mathrm{ml})$ in vergelijking met conventionele TKP. Echter was de fractie outliers (meer dan 3 graden deviatie van een neutrale beenas) nog hoger dan verwacht $(30 \%$ versus $50 \%$ met $\mathrm{Cl}$ ).

De initiële gebruikerservaring met PSM was in zijn algemeenheid positief in vergelijking met $\mathrm{Cl}$ en derhalve stelden we het doel om beide technieken in meer 
detail met elkaar te vergelijken in een gerandomiseerde trial. De resultaten van deze trial werden gepresenteerd in hoofdstuk 4 en 5 . Echter, aangezien de fractie outliers vrij hoog was, startten we een extra studie om de potentiele achilleshiel van PSM te achterhalen. Het basisdoel van PSM is het adequaat reconstrueren van het pre-operatieve plan en we analyseerden daarom in hoeverre de techniek dit kan waarmaken. Deze resultaten presenteerden we in hoofdstuk 3.

Meer specifiek was het doel van hoofdstuk 3 om te analyseren of er een significant verschil bestaat tussen de uitlijning van de individuele femur en tibia componenten van de TKP (in het frontale, sagittale en horizontale vlak) zoals die pre-operatief werd berekend en de uiteindelijk bereikte uitlijning na operatief ingrijpen.

Zesentwintig patiënten werden geïncludeerd in deze trial. Software werd gebruikt om de per-operatieve MRI-scan (en daarmee ook de berekende positie van het implantaat) te matchen met een pre-operatieve CT-scan. Deze laatste werd vervolgens weer gematcht met de postoperatieve CT-scan om de afwijkingen van de pre-operatieve planning in alle 3 de vlakken te kunnen objectiveren.

We concludeerden uit dit hoofdstuk dat PSM in staat waren om adequaat het preoperatieve plan te reproduceren, behalve voor wat betreft de rotatie van de tibiacomponent in het horizontale vlak. We bediscussieerden en benadrukten verder het belang van een adequate training van de orthopedisch chirurg alvorens te starten met gebruik van PSM voor TKP.

Zoals reeds eerder aangegeven, brachten de resultaten uit hoofdstuk 2 ons ertoe om een prospectief, dubbelblinde, gerandomiseerde trial op te zetten. Hoofdstuk 4 beschrijft deze trial met de volgende onderzoeksvragen: ten eerste, is er een significant verschil in outliers bij de uitlijning van de TKP in het frontale en sagittale vlak tussen TKP geplaatst m.b.v. PSM en conventionele TKP. Ten tweede, is er een significant verschil in operatietijd, bloedverlies en opnameduur tussen beide technieken. Honderdtachtig patiënten werden gerandomiseerd voor PSM TKP of conventionele TKP in twee centra.

We concludeerden uit dit hoofdstuk dat de resultaten voor het verkrijgen van een neutrale mechanische as en een correcte positie van de prothesecomponenten niet verschilden tussen PSM en $\mathrm{Cl}$. Een kleine reductie van de operatietijd (5 minuten, $\mathrm{p}<$ $0.001)$ en bloedverlies $(100 \mathrm{ml}, \mathrm{p}<0.001)$ werd gevonden met de PSM, maar de opnameduur in het ziekenhuis was identiek (gemiddeld 3,6 dagen, niet significant) aan die van $\mathrm{Cl}$.

In hoofdstuk 5 presenteerden we de klinische uitkomsten en het aantal complicaties na middellange follow-up (minimaal 2 jaar) van de patiënten uit de gerandomiseerde trial beschreven in hoofdstuk 4. 
We concludeerden dat er geen significant of klinisch relevant verschil zat tussen PSM en $\mathrm{Cl}$ ten aanzien van de uitkomsten van de vragenlijsten en dat er geen verschil was in TKP gerelateerde complicatie percentage.

Uit hoofdstuk 2, 3, 4 en 5 is het duidelijk dat PSM veilig waren in gebruik en dat de uitkomsten in vergelijking met $\mathrm{Cl}$ niet inferieur waren voor wat betreft correcte uitlijning of klinische uitkomst. Echter, de bevindingen uit ons onderzoek toonden ook geen substantiële verbetering voor deze uitkomstmaten. Theoretisch gezien zou de techniek achter PSM in staat moeten zijn om pre-operatief de juiste implantaatgrootte vast te stellen op basis van de beeldvorming met MRI of CT-scan. Het voorspellen van de implantaatgrootte zou potentieel kunnen leiden tot een reductie in kosten die geassocieerd zijn met TKP chirurgie. We onderzochten de potentie van PSM om dit te verwezenlijken in een aparte studie (hoofdstuk 6).

In deze studie in hoofdstuk 6, presenteerden we de resultaten van een serie van 200 opeenvolgende TKP cases die geopereerd werden door 1 enkele chirurg en die een minimale follow-up hadden van 2 jaar. Operatietijd, accuratesse van de voorspelling van de implantaatgrootte en percentage outliers (>3 graden) van de mechanische as werden geanalyseerd in dit cohort.

Er waren geen cases waarbij peroperatief geconverteerd moest worden naar conventioneel instrumentarium. Gemiddelde operatietijd was 52 minuten. Er was geen leercurve m.b.t. operatietijd in dit cohort. De voorspelling van de componentgrootte met een foutmarge van 1 maat was correct in 98,5\% van de femurcomponenten en $97 \%$ van de tibiacomponenten. Het preoperatief beoordelen en accorderen van het digitale plan reduceerde het aantal maataanpassingen peroperatief van $21.5 \%$ naar $14 \%$ voor de femurcomponent en van $41 \%$ naar $29.5 \%$ voor de tibiacomponent. Gemiddelde mechanische as week 0.5 graden af van een neutrale beenas met een percentage outliers $>3^{\circ}$ van de digitale planning van $20.7 \%$.

We toonden in dit hoofdstuk het belang van het kritisch reviewen van het digitale preoperatieve plan om voldoende te kunnen vertrouwen op de voorspelling van de componentgrootte. De vraag of PSM hiermee ook de kosten van TKP chirurgie kan reduceren blijft moeilijk te beantwoorden en verder onderzoek zal nodig zijn om dit issue in meer detail te analyseren.

Lange beenas opnamen (LBO) worden vaak gebruikt in de orthopedie om de beenas (en percentage outliers van een neutrale beenas) te beoordelen bij patienten die een totale knie prothese (TKP) ondergaan. Tijdens het uitvoeren van het onderzoek van deze thesis ontstonden twijfels over de betrouwbaarheid van metingen op LBO. Om die reden hebben we een aparte studie opgezet om de betrouwbaarheid en de validiteit van metingen op LBO, waarbij gebruik gemaakt werd van 3D CT-scans als gouden standaard, te analyseren. 
In hoofdstuk 7 maten zes verschillende chirurgen de mechanische as en de positie van de femur en tibiacomponent op 24 LBO. Intraclass correlatiecoëfficiënten (ICC) werden berekend om de betrouwbaarheid vast te stellen en Bland-Altman plots werden geconstrueerd om de overeenkomst tussen metingen op LBO en 3D CT-scans te analyseren.

We concludeerden uit dit hoofdstuk dat metingen op LBO een gemiddelde tot goede betrouwbaarheid tonen en, wanneer vergeleken met 3D CT-scan, een goede validiteit.

Tenslotte plaatsten we in hoofdstuk 8 onze bevindingen in een bredere context en beantwoordden we de gestelde vragen uit de introductie (hoofdstuk 1).

In het tweede deel van dit hoofdstuk bediscussieerden we de uitdagingen die zouden ontstaan wanneer PSM op grotere schaal geïntroduceerd zouden worden voor TKP chirurgie. Waarschijnlijk is de belangrijkste vraag hierbij hoe om te gaan met het medicolegale aspect van het gebruik van PSM. Medicolegale experts hebben aangegeven dat de industrie primair verantwoordelijk is wanneer PSM worden gefabriceerd en geleverd zonder voorafgaande validatie van de planning door de orthopedisch chirurg. Er bestaat echter geen twijfel dat de orthopedisch chirurg zelf uiteindelijk verantwoordelijk is voor de correcte plaatsing van de TKP componenten, welke methode hier ook voor gebruikt wordt.

Tweede grote uitdaging bij het gebruik van PSM draait om het logistiek verhaal. Het traject van uitvoeren van MRI of CT-scan, uploaden van de beelden naar de planningsingenieurs voor het construeren van het digitale pre-operatieve plan, checken en accorderen van dit plan door de orthopedisch chirurg, tijdig afleveren van de mallen en digitale plan en sterilisatie van de mallen voor peroperatief gebruik stelt specifieke eisen aan de hele organisatie.

Derde uitdaging ligt in het trainen van opleidingsassistenten tot orthopedisch chirurg. Idealiter zouden zij zowel $\mathrm{Cl}$ als PSM moeten beheersen als technieken voor het plaatsen van een TKP. Wanneer de operatieve stappen en theoretische kennis van het plaatsen van een conventioneel geïnstrumenteerde TKP voldoende beheerst worden, kan de techniek van PSM veilig aangeleerd en gebruikt worden.

In Nederland wordt iedere geplaatste knieprothese geregistreerd in een centrale database (LROI: landelijke registratie orthopedische implantaten). Tal van informatie wordt hierin vastgelegd, maar het type methode dat gebruikt wordt voor het uitlijnen van een prothese wordt niet geregistreerd. Met het introduceren van steeds meer uitlijningsmethoden, zou het interessant zijn om deze informatie wel te verzamelen. Op de lange termijn zou het ons in staat kunnen stellen om conclusies te trekken over de veiligheid van de verschillende systemen en over het aantal revisieprocedures.

Concluderend kunnen we stellen dat PSM zeker een plaats verdienen als een uitlijnmethode voor een TKP. In dit stadium zijn PSM vooral nog te beschouwen als evolutie in TKP chirurgie eerder dan als revolutie. 